\title{
CYTOLOGICAL EXAMINATION OF SPUTUM IN RELATION TO ITS MACROSCOPIC PURULENCE
}

BY

\author{
G. A. RAWLINS \\ From the Institute of Diseases of the Chest, Brompton Hospital, London
}

(RECEIVED FOR PUBLICATION SEPTEMBER 30, 1954)

Investigations into the bacteriology of chronic bronchitis (May, 1953a and b) have shown that purulent sputum usually contains one or more pathogens and that such a sputum can be rendered mucoid, at any rate temporarily, when the patient is treated with the appropriate antibiotic. Subsequent studies (May, 1954) included patients diagnosed clinically as infected asthma, and the macroscopical appearance of the sputumfrom these patients suggested the presence of pus, although in many instances pathogenic organisms could not be demonstrated and chemotherapy failed to alter its appearance. Examination of the cellular contents of such sputa showed that in most cases the "pus " consisted mainly of eosinophils. As a result of these observations investigations have been undertaken to develop a satisfactory method for the cytological examination of sputum, for the distinction between neutrophil and eosinophil "pus" is clearly of great importance.

The examination of single smears of sputum for eosinophils is of little value, since the distribution of these cells is often irregular (see below). The sputum must, therefore, be homogenized in order to obtain an even suspension of cells before the film is made. 'Pancreatin used for this purpose (Rawlins, 1953) does not cause cellular destruction.

This paper describes a method whereby the total number of cells per unit volume of sputum can be estimated as well as the relative number of eosinophils.

\section{Method}

Preliminary Washing of the Sputum.-In order to free the sputum as far as possible from adherent saliva it is first rinsed in about five times its volume of physiological saline solution, which is then removed by means of a Pasteur pipette.

Liquefaction of the Sputum.-The specimen is liquefied by the addition of $1 \%$ pancreatin solution buffered to
pH 7.6 (Rawlins, 1953). A measured volume of the solution is added to approximately an equal volume of $\vec{A}$ sputum; the mixture is thoroughly shaken and is then 을 incubated in a water-bath at $37^{\circ} \mathrm{C}$. until liquefaction is complete. The total volume of the liquefied sputum $\bar{z}$ is measured, and, knowing the volume of pancreatin used, the dilution of the sputum is calculated.

The Total Cell Count.-A drop of the liquefied of sputum, previously well shaken to ensure uniform suspension of the cells, is placed in a Neubauer haemocytometer and the cells are enumerated by the standard methods applicable to cell counting in other fluids. In $\bar{\partial}$ most instances no additional dilution of the sputum is required, but occasionally, for exceptionally cellular市 specimens, the sputum may require further dilution before accurate counting is possible.

The Differential Cell Count.-A film of the liquefied $\frac{3}{\sqrt{3}}$ sputum is dried on a microscope slide, fixed in methyl alcohol, and stained with haematoxylin and eosin or Leishman's stain. A representative number of cellso (100 are usually sufficient) are counted under the microscope and the relative number of each type of celB determined. In this investigation interest centredo particularly on the eosinophils in sputum and various staining methods, both wet and dry, were tested. Haematoxylin and eosin gave the most consistently satisfactorys results, though Leishman was often almost as good. In some sputa in which most of the cells were degenerate haematoxylin and eosin was definitely superior, anc this method has been adopted for routine use.

\section{Results}

Distribution of Eosinophils in Unliquefied Sputum. -Table I shows examples illustrating the irregulaf distribution of eosinophils which may be encountere in macroscopically purulent sputum.

Survival of Leucocytes in Sputum Liquefied bo Pancreatin.- - In order to demonstrate that pancreatio had no lytic effect on cells in sputum, 12 specimens were liquefied and total cell counts performed immediately after liquefaction and again aftem 
TABLE I

UNEVEN DISTRIBUTION OF EOSINOPHILS AND NEUTROPHILS IN PURULENT SPUTA*

\begin{tabular}{c|c|c|c}
\hline \multirow{2}{*}{ Sputum } & \multirow{2}{*}{ Film } & \multicolumn{2}{|c}{ Percentage of Polymorphs } \\
\cline { 2 - 4 } & & Eosinophils & Neutrophils \\
\hline 1 & 1 & 86 & 14 \\
2 & 2 & 8 & 92 \\
3 & 1 & 57 & 43 \\
4 & 2 & 10 & 90 \\
& 1 & 73 & 27 \\
& 2 & 41 & 96 \\
& 1 & 28 & 72 \\
\hline
\end{tabular}

* Films were made from different parts (all macroscopically purulent) of each sputum. They were stained with haematoxylin and eosin and differential counts of the types of polymorphs were made. The total number of cells counted in each smear was 500 . made. The total number of cells counted in each smear was 500 . The figures in the table show the variations in the proportions of
eosinophils and neutrophils in films from two different parts of each specimen.

24 hours of standing at room temperature. Within the limits of experimental error for the counting technique the same counts were obtained for each pair of observations.

The possibility that pancreatin might destroy cells during the period in which liquefaction was taking place could not be investigated in sputum, owing to the impossibility of estimating the number of cells present before liquefaction. However, no diminution in the cell count, apart from that caused by the dilution when pancreatin was added, was found when purulent pleural fluids were incubated with pancreatin, suggesting that the cells in sputum were also unlikely to be destroyed.

Relationship between Total Cell Counts and Macroscopic Appearances of Sputum.-Enumeration of the total cells has been carried out in 602 specimens of sputum. The relationship between the counts and the macroscopic appearances of the specimens is shown in Table II.

TABLE II

MACROSCOPIC APPEARANCE AND TOTAL POLYMORPH CONTENT OF 602 SPECIMENS OF SPUTUM

\begin{tabular}{|c|c|c|c|}
\hline \multirow{2}{*}{$\begin{array}{l}\text { Macroscopic } \\
\text { Appearance }\end{array}$} & \multirow{2}{*}{$\begin{array}{c}\text { No. of } \\
\text { Specimen; }\end{array}$} & \multicolumn{2}{|c|}{ No. of Cells (per c.mm.) } \\
\hline & & Range* & Mean $\dagger$ \\
\hline Thi k pus ... ... & 53 & $7,000-89,000$ & $32,6 \mathrm{CO}$ \\
\hline dominantly pus) ... & 182 & $1,500-50,000$ & 15,700 \\
\hline $\begin{array}{l}\text { Pus and mucus (pre- } \\
\text { dominantly mucus) }\end{array}$ & 162 & $500-8,000$ & 2,686 \\
\hline Mucus $\quad \ldots \quad \ldots$ & 205 & $38-3,000$ & 837 \\
\hline
\end{tabular}

* "Range " = extreme limits of cell counts in each type of sputum. + "Mean" = the mean of the counts of all the specimens in each class of sputum.

\section{Discussion}

Routine determination of the number and nature of the cells in sputum presents difficulties, and it is not suggested that the complete total and differential counting method described here should be employed in every patient. Estimation of the total number of cells per unit volume of sputum has very limited practical value. As will be seen from Table II the correlation between macroscopic purulence and the cell content of sputum is very poor. This is understandable in the light of the observation of Elmes and White (1953) that desoxyribonucleoprotein (D.N.P.) fibres, derived from the breakdown of polymorphs, are often responsible for much of the macroscopic purulence of sputum. Elmes and White state that in the early stages of acute exacerbations of chronic bronchitis polymorphs are exceedingly numerous in the sputum, but later their number falls and D.N.P. fibres increase. Clearly, therefore, day-to-day enumeration of the cells in the sputum would provide no guide to the progress of this type of patient. In patients with chronic bronchitis who have no acute exacerbation, however, the cell content of the sputum has been found in this laboratory to remain relatively constant from day to day before treatment, and changes in the cell counts in these patients have been useful in assessing the results of treatment. Mention of the use of the total cell-counting technique for this purpose was made in an earlier report by May (1953b).

Although enumeration of the total cells in sputum on one occasion only has little practical value, the differential count is important. For routine purposes a count is probably unnecessary, but a film should always be stained and the cells examined in order to be certain that apparent " "pus" is really composed of neutrophils and not mainly of eosinophils. Owing to the irregular distribution of eosinophils in some specimens of sputum, especially those containing neutrophils also (Table I), a single smear from the unliquefied sputum is unreliable. Mechanical methods of homogenization, such as shaking with glass beads, are liable to destrcy the cells, and some form of enzymatic digestion is therefore required. The use of pancreatin is very satisfactory.

The techniques described in this paper were evolved as part of a study of the chemotherapy of chronic respiratory infections. It is possible that liquefaction by pancreatin may also be valuable in the search for malignant cells in sputum, since after liquefaction the cells can be concentrated by centrifugation, thus allowing a far greater number to be examined than is possible when smears from unliquefied sputum are used. 


\section{Summary}

The distinction between neutrophils and eosinophils in macroscopically purulent sputum is important, since the "pus" in some instances is composed mainly of eosinophils.

A method is described for enumerating both the total cells per unit volume of sputum and the proportion of eosinophils and neutrophils. Since eosinophils are often irregularly distributed in the sputum preliminary homogenization by the actiono of pancreatin is required.

I wish to thank Dr. J. R. May for his help and adviceo in the preparation of this article.

\section{REFERENCES}

Elmes, P. C., and White, J. C. (1953). Thorax, 8, 295. May, J. R. (1953a). Lancet, 2, 534. - (1953b). Ibid., 2, 899.

(1954). Ibid 2, 839

Rawlins, G. A. (1953). Ibid., 2, 839. 